Poetics and Politics 



\section{Poetics \\ and Politics}

Net Structures and Agencies in Early Modern Drama

Edited by

Toni Bernhart, Jaša Drnovšek, Sven Thorsten Kilian, Joachim Küpper, Jan Mosch

\section{DE GRUYTER}


This book is published in cooperation with the project DramaNet, funded by the European Research Council

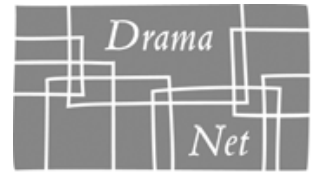

Early Modern European Drama and the Cultural Net

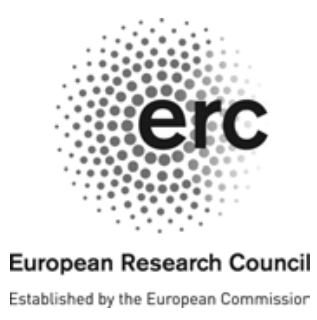

Established by the European Commissior

ISBN 978-3-11-053665-2

e-ISBN (PDF) 978-3-11-053669-0

e-ISBN (EPUB) 978-3-11-060352-1

\section{(cc) BY-NC-ND}

This work is licensed under the Creative Commons Attribution-NonCommercial-NoDerivs 4.0 License. For details go to http://creativecommons.org/licenses/by-nc-nd/4.0/.

Library of Congress Cataloging in Publication Control Number: 2018017860

Bibliographic information published by the Deutsche Nationalbibliothek

The Deutsche Nationalbibliothek lists this publication in the Deutsche Nationalbibliografie; detailed bibliographic data are available on the Internet at http://dnb.dnb.de.

(c) 2018 Toni Bernhart, Jaša Drnovšek, Sven Thorsten Kilian, Joachim Küpper, Jan Mosch, published by Walter de Gruyter GmbH, Berlin/Boston

Typesetting: Meta Systems Publishing \& Printservices GmbH, Wustermark

Printing and binding: $\mathrm{CPI}$ books $\mathrm{GmbH}$, Leck

Cover illustration: photodeedooo/iStock/Thinkstock

www.degruyter.com 